\title{
The Syntax and Semantics of Clause-Chaining in Toposa ${ }^{1}$
}

\author{
Helga Schröder \\ University of Nairobi
}

\begin{abstract}
Some languages make extensive use of clause-chaining. According to Payne (1997: 312), clause-chaining has been documented for languages in the highlands of New Guinea, Australia and the Americas. In Africa it is found in Ethiopia (Völlmin et al. 2007), in Kiswahili, a Bantu language (Hopper 1979: 213-215, Mungania 2018), in Anuak, a Western Nilotic language (Longacre 1990: 88-90 and 2007: 418) and in Toposa, a VSO language of South Sudan (Schröder 2011). Clause-chaining is characterized by a long combination of non-finite clauses that have operator dependency on a finite clause, and it usually signals foregrounded information in discourse (see also Dooley 2010: 3). Besides its discourse function, clause-chaining exhibits morpho-syntactic and semantic properties as demonstrated in this paper with examples from Toposa, an Eastern Nilotic language.
\end{abstract}

Keywords: clause-chaining, foreground-background distinction, clause-chaining model, clause-skipping, discourse structuring.

\section{Introduction}

Some of the world's languages occur with extensive use of clause-chaining. Clause-chaining is found widely in SOV languages in Papua New Guinea (Elson 1964), in Australian languages (Austin 1979), in North American Indian languages (Longacre 1990), and in South America, Korea and Japan (Longacre \& Hwang 2012). In Africa it is prevalent in SOV languages in Ethiopia (Völlmin et al. 2007), and it is reported for three SVO languages Kiswahili and Kisukuma, both Bantu languages (Hopper 1979: 213-215, Mungania 2018, Mbuki 2019), and Anuak, a Western Nilotic language (Longacre 1990: 88-90 and 2007: 418). I have argued recently that Toposa, an Eastern Nilotic language in South Sudan is also a clause-chaining language because of the way it organizes its discourse (Schröder 2011). However, Toposa is VSO.

In East Africa the clause-chaining phenomenon surfaces as narrative tense (Kiswahili), converbs (Ethiopia) or consecutive tense (Bantu/Tanzania). Particular the converbs in Ethiopia from Afroasiatic languages have attracted attention and discussions (see Völlmin et al. 2007). Converbs and clause-chaining effects have recently also been discovered in some Nilo-Saharan languages (Amha \& Dimmendaal 2006).

This paper will show that the phenomenon of clause-chaining as described in Toposa cannot be regarded as a morpho-syntactic phenomenon only that conceptualises narrative or consecutive tense. A better option is to analyse clause-chaining as a discourse feature, because it motivates and underlines the structuring of texts; a fact which has so far been overlooked for a number of Nilotic and Bantu languages in East Africa.

This paper will demonstrate the typical characteristics of Toposa clause-chaining i.e. its morpho-syntactic and semantic properties, the foreground-background distinction, the reference tracking in the chains and several strategies that cause the chains to end. It will demonstrate its distribution i.e. that the non-finite verb form of the clause chains is not restricted to coordinative

\footnotetext{
${ }^{1}$ This paper was presented in Pavia, Italy, at the conference on 'Syntax of the World's Languages VI', from $8^{\text {th }}$ to $10^{\text {th }}$ September 2014. I thank all who attended the presentation for their valuable contributions.
} 
sentence structure only, but that it is also found in purpose and means-results subordinative sentence linkages.

The paper is organized as follows: Section 2 describes the characteristics of clausechaining in Toposa i.e. its morphosyntactic and semantic features and the foreground-background distinction, section 3 discusses the clause-chaining model, section 4 deals with the reference tracking in the clause chains, section 5 presents a discussion how clause-chaining motivates the structuring of a discourse and section 6 will present the conclusion.

\section{Characteristics of clause-chaining in Toposa}

Clause-chaining has been defined in different ways. One common understanding is that clausechaining characterizes non-finite clauses that show operator dependencies on the finite clause (Dooley 2010: 3, Payne 1997: 312, Longacre 1990: 11, Myhill \& Hibiya 1988: 363). The finite clause can stand on its own and carries all the inflectional features like tense, aspect and mood (TAM) on a finite verb and is often referred to as the main clause in a coordinative-subordinative sentence construction. In a coordinative-clause-chaining combination the finite clause is referred to as the 'controlling clause', as it controls the TAM dependency. I shall refer to the non-finite clauses as medial clauses as coined by Haiman (1987), also mentioned in Bianti (2007:3). ${ }^{2}$

The next section will demonstrate the morpho-syntactic properties and the correlation of clause-chaining to the foreground-background distinction in Toposa.

2.1 Morpho-syntactic properties of clause-chaining. This section will discuss the morphosyntactic properties and the orientation of the chain with data from Toposa ${ }^{3}$ and considers the properties of clause chaining and the status of the finite and non-finite clause.

Let us look first at the morpho-syntactic properties of clause-chaining in Toposa, i.e. the operator dependency of tense/aspect of the non-finite verb, and the orientation of the chain.

Clause-chaining languages typically indicate the dependence on the controlling clause through morpho-syntactic means and they also determine the direction of the chain through the word order, which is either prenuclear in SOV languages, or postnuclear in SVO/VSO languages.

In Toposa, a typical clause chain starts with a controlling clause that is inflected for tense and aspect, whereas the verbs in the subsequent medial clauses carry the dependency markers to/ki- which signal tense-aspect dependency on the finite verb or on a temporal adverbial that sets the time frame in the controlling clause ${ }^{4}$, as in the following example (taken from Schröder 2013: 27):

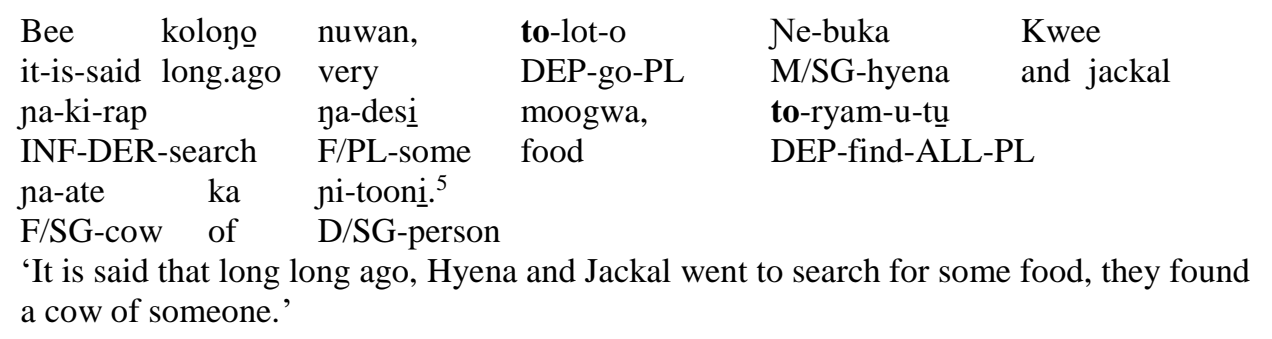

\footnotetext{
${ }^{2}$ Van Valin \& LaPolla (1997: 455) describe the dependency of chained clauses in terms of TAM operator dependency.

${ }^{3}$ The data for this research are based on a collection of oral Toposa texts complied in M. Schröder (2010).

${ }^{4}$ Longacre (2007) identifies such an opening for clause chains as implicit finiteness.

${ }^{5}$ Note that +/- ATR has not been marked in these data. Underlined vowels at the end of words indicate voiceless vowels.
} 
The above sentence represents a typical beginning of an animal fable. The story is set with the formula bee 'it is said' and the adverbial kolono nuwan that sets the time frame to the past and the following sentences are chained to the initial clause with the dependency marker to- in toloto 'they went' and in toryamutu 'they found'. Both verbs do not have the typical inflection that marks person, tense, and aspect on finite verbs. Compare these verbs with fully inflected ones (taken from Schröder 2008: 51):
a. É-múj-ì
1P-eat-PRS:IMP
ná-kírîn. ${ }^{6}$
'I am eating meat.'
F/SG-meat
b. İ̀múj-ì
3P-eat-PRS:IMP
'He is eating meat.'
ná-kírîn.
c. È-múj-în ná-kírîn.
1P-eat-PST:IMP F/SG-meat
'I was eating meat.'
d. È-mùj-í já-kírîy.
3P-eat-PST:IMP F/SG-meat
'He was eating meat.'

As these data show, the normal finite Toposa verb is marked for tense, aspect, person, and number. The tense system is a past and non-past type. Tense in Toposa is marked by the tone pattern that extends over the entire verb and varies according to verb class, person, number, and tense category. In addition to the tone pattern, a tense prefix $a$ - occurs in the third person singular and plural in the past tense. In example (2c) and (2d), this tense prefix $a$ - has become fused with the person agreement prefix $i$-, resulting in $e^{-}$(for a more detailed description of the fusion of the past marker in TO and KI-class verbs see Schröder 2008: 53). Note how the tone pattern on the verb for first-person singular changes from HHL in (2a) to LHF in (2c) to mark the change from non-past to past. Similarly, the third-person changes from LHL in (2b) in non-past to LLH in (2d) in the past.

Additionally, Toposa has two aspects: imperfective and perfective. Imperfective aspect is indicated by the suffix $-i$, as shown in the above data. ${ }^{7}$ The perfective aspect is indicated by the suffix -itii:

$$
\begin{aligned}
& \text { É-múj-îti } \quad \text { ná-kírîn. } \\
& \text { 1SG-eat-PFV F/SG-meat/ACC } \\
& \text { 'I have eaten meat.' }
\end{aligned}
$$

As these comparisons show, the two verbs toloto 'they went' and toryamutu 'they found' of example (1) do not have the typical tense-aspect inflection of the finite Toposa verb, they represent a non-finite form. Note also that they do not employ the typical person agreement marking as shown in example (2a-b).

The question that scholars are concerned with in regard to the non-finite clause in clause chains is whether the non-finite clause is coordinative or subordinative in nature. These non-finite clauses are exemplified in example (1) as those clauses that start the clause with the to- prefixed to

\footnotetext{
${ }^{6}$ Note that the personal pronoun is usually not expressed as a free word but is integrated as an argument in the verb (Schröder 2008: 111).

7 The imperfect marker has an allomorph -e before the plural suffix - $t e$, used in second and third person plural. First person plural uses the suffix $-i$ with the plural suffix $-o$.
} 
the verb, where the verb has lost those inflectional features of tense and aspect exemplified in the examples (2).

Some scholars point out that the non-finite clause in clause-chaining is like a coordinative clause (Roberts 1988: 4, 1997: 183, also Haspelmath 1995: 12-17, 2007: 46f). Stirling (1993: 195198) discusses that in Papua New Guinean languages and mentions these clauses have been termed coordinative, citing Haiman (1980, 1983), Comrie (1983), and MacDonald (1983), among others. However, in Toposa, the non-finite clause shows morpho-syntactic dependency on the independent clause through the verbal prefixes to/ki. The dependency is of such a kind that the infinite clause picks up the TA inflection from the finite clause as in the case of example (1) and the medial clause continues to exhibit past tense. As this morpho-syntactic property of the non-finite clause exhibits morpho-syntactic dependency as an implicit inflectional property some scholars call it "quasicoordinate" (Haiman \& Munro 1983: xii, Stirling 1993: 15), because the clause shares with the coordination the inflectional property of past tense. Van Valin \& LaPolla (1997: 455) add another dimension to the discussion they point out that a medial clause has semantically coordinative effects because it chains events in the narrative. In this respect the medial clause in example (1) displays the semantic coordination of the events of toloto 'they went' and toryamutu 'they found', but morpho-syntactically the events dependent on the tense introduced through the formal opening of a narrative with the formula bee 'it is said' and the adverbial kolono nuwan 'long ago' setting the time frame to the past. Van Valin and LaPolla call this clause linkage "cosubordination".

For a better understanding of the two paradigms the following examples demonstrate the difference between the inflected and dependent verb forms in Toposa for a KI-class verb (a-d) and a TO-class verb (e-h) ${ }^{8}$ (Schröder 2015a: 234-235).

$$
\begin{aligned}
& \text { a. è-mùj-í } \\
& \text { 3P-eat-IMP } \\
& \text { 'He was eating (inflected form).' } \\
& \text { b. kí-múj } \\
& \text { DEP-eat } \\
& \text { 'He was eating (dependent form).' } \\
& \text { c. è-mùj-é-té } \\
& \text { 3P-eat-IMP-PL } \\
& \text { 'They were eating (inflected form).' } \\
& \text { d. kí-múj-à } \\
& \text { DEP-eat-PL } \\
& \text { 'They were eating (dependent form).' } \\
& \text { e. á-lòs-í } \\
& \text { 3P-go-IMP } \\
& \text { 'He was going (inflected form).' } \\
& \text { f. tó-lót } \\
& \text { DEP-go } \\
& \text { 'He went (dependent form).' }
\end{aligned}
$$

\footnotetext{
${ }^{8}$ Like most Eastern Nilotic languages Toposa has two verb classes. The distinction between the verb classes relies on the person prefixes that are associated with the classes. In the TO-class the personal prefixes in the order of $1 \mathrm{st} / 2 \mathrm{nd} / 3 \mathrm{rd}$ person $\mathrm{SG}$ and $1 \mathrm{st} / 2 \mathrm{nd} / 3 \mathrm{rd}$ person PL are: $a-, i-, e-, e, i-, e-$, in the Ki-class the person prefixes are $e^{-}, i-, i-, i-, i-, i$. The marker TO and $\mathrm{KI}$ are taken from the respective imperative markers.
} 
g. á-lòs-é-té

3P-go-IMP-PL

'They were going (dependent form).'

h. tó-lót-ò

DEP-go-PL

'They went (dependent form).'

Examples (5a-b) below demonstrate how the dependency marking would differ in first person singular and plural in personal narratives (Schröder 2015a: 233):

$$
\begin{aligned}
& \text { a. a-to-loto } \\
& \text { 1P-DEP-go } \\
& \text { 'I go/went.' }
\end{aligned}
$$

b. $\quad$... a-to-lot-o

1P-DEP-go-PL

'We go/went.'

As the first person is marked with an overt prefix preceding the dependency marker of the medial verb, the assumption is that even DEP verb forms have a slot for marking the (coreferential) person on the verb, but they are only overt in the first person singular and plural, but zero in the third person.

Example (5a-b) are not finite verbs, they depend on a finite clause. A clause from a first person narrative shall demonstrate the use of the first person plural non-finite medial verb in a chain (Schröder 2015a: 233):

$$
\begin{aligned}
& \text { Kolono ki-rin-a diri isuwa ki-ra ni-soroko, } \\
& \text { long ago DEP-be.still-PL truly we.EX DEP-be M/PL-young.men } \\
& \text { a-to-lom-a na-kopo na a-bee-I Nakamoyo. } \\
& \text { 1P-DEP-enter-PL F/SG-place which 3P-call-IMP Nakamono } \\
& \text { 'Long ago [when] we were still young men, we settled in a place called Nakamongo.' }
\end{aligned}
$$

The non-finite forms of the verb are not normal infinitives, however. This can be seen from constructions like the following (Schröder 2013: 28):

$$
\begin{array}{llll}
\text { To-lot-o Ne-bu ka Kwee na-ki-rap } & \text { na-desi } & \text { moogwa. } \\
\text { DEP-go-PL M/SG-hyena and jackal INF-DER-search } & \text { F/PL-some food } \\
\text { 'Hyena and Jackal went to search for some food.' } & &
\end{array}
$$

The verb nakirap 'to search' represents the typical infinitive form, which consists of the prefix $n a-$ and the derivation prefix $k i-.^{9}$

Example (6) and (7) also show that the direction of the chain is post-nuclear, i.e. that the controlling clause precedes the medial clauses. The post-nuclear orientation of medial clauses is still a rare phenomenon (Dooley 2010: 6 and Payne 1997: 321), mainly because most cases of clausechaining presented in the literature were found in SOV languages, whereas Toposa is a verb-initial language.

\footnotetext{
${ }^{9}$ The derivation prefix occurs only when there is no verbal extension like allative, ablative, or benefactive. I am fairly certain that this is only true of TO-class verbs, KI-class verbs retain the ki- prefix.
} 
2.2 Foreground/background distinction. I classified Toposa as a clause-chaining language (Schröder 2011) because it structures its discourse according to clause-chaining. The reason is that not all languages that indicate a TAM dependency in non-finite clauses are typical clause-chaining languages but only those whose discourse structure is organised through clause-chaining, a fact that will be demonstrated for Toposa in the following section.

The TAM marking in narratives has often been related to the distinction between foreground and background information as stated by Unger (2006: 306, among others). Under functional linguistic approaches, foregrounded events typically represent the event line of a story and are chronologically ordered. Representatives of this position are Hopper (1979/1998), Reinhart (1984), Fleischman (1985, 1990), Longacre (1990) and Longacre \& Hwang (2012). ${ }^{10}$ In line with this position, a typical understanding of foregrounded information is that it can be regarded as thematic information that develops and progresses the plot (or the arguments of a text), i.e. it represents the backbone of a text that carries the discourse forward and is of primary importance (Callow 1974: 52-53, Levinsohn 2010: 66). Background information on the other hand supports, explains and clarifies the thematic information and is of secondary importance, as described in Grimes (1975) and Levinsohn (2010: 69-71), among others.

As discussed in the previous section, in Toposa, the clause chain markers to-/ $k i$ - are verbal prefixes that indicate in all medial clauses that the medial verb has the same tense/aspect as the verb in the controlling clause (which in narratives usually is a form of past tense).

For a demonstration of how the to-/ki- markers work for the distinction of background and foreground information, I shall examine three types of texts: a narrative, a procedural and a descriptive-expository text. ${ }^{11}$

First, let us consider the beginning of a narrative (taken from M. Schröder 2010: 6):

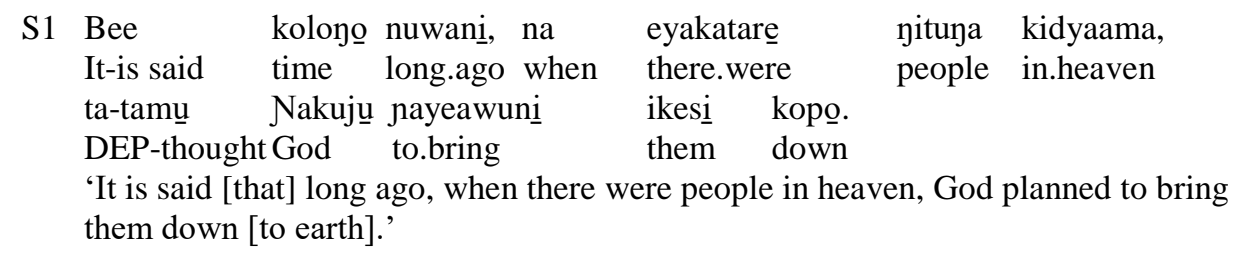

S2 Abu Nakujụ, to-limoki came God, DEP-told tem, "To-woyiu

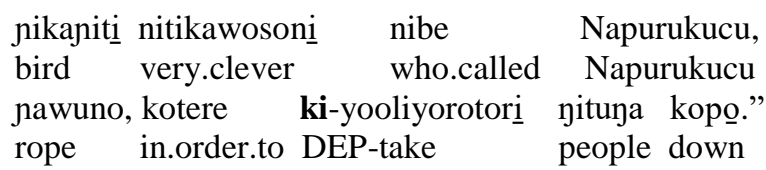
DEP:said IV-twist people down
ucu (= Orange 'God came, he told a very clever bird whose name was called
Starling), he said, Twist a rope in order to take people down.'

S3 To-woyiu nai Napurukucu naputu natikaanikani, to-woi loowoi. DEP-twisted so Napurukucu tendon-string which.strong DEP-long very 'So Napurukucu twisted a strong tendon-string, it was very long.'

\begin{tabular}{|c|c|c|c|c|c|}
\hline & $\begin{array}{l}\text { Ki-yooliwunoe } \\
\text { DEP-were-let-down }\end{array}$ & $\begin{array}{l}\text { nai } \\
\text { so }\end{array}$ & $\begin{array}{l}\text { yituna, } \\
\text { people, }\end{array}$ & $\begin{array}{l}\text { ki-bitibitiuni } \\
\text { DEP-let.themselves }\end{array}$ & $\begin{array}{l}\text { kopo, } \\
\text { down, }\end{array}$ \\
\hline & $\begin{array}{ll}\text { ka } & \text { yide } \\
\text { and } & \text { children }\end{array}$ & & $\begin{array}{l}\text { tya } \\
\text { and }\end{array}$ & $\begin{array}{l}\text { nikecekilyoko. } \\
\text { husbands-theirs }\end{array}$ & \\
\hline
\end{tabular}

\footnotetext{
${ }^{10}$ An extensive discussion of the different views on how the TAM distinction contributes to the foregroundbackground distinction is found in Unger (2001: 98-130), and (Unger 2006: 3-5).

${ }^{11}$ Note that the term "procedural" here refers to a type of text as defined in Longacre (1996: 10), not to the sense in which it is used in Relevance Theory (Sperber \& Wilson 1995: 258), see also example (10).
} 
'The people were let down, they let themselves down, the women and children and their husbands.'

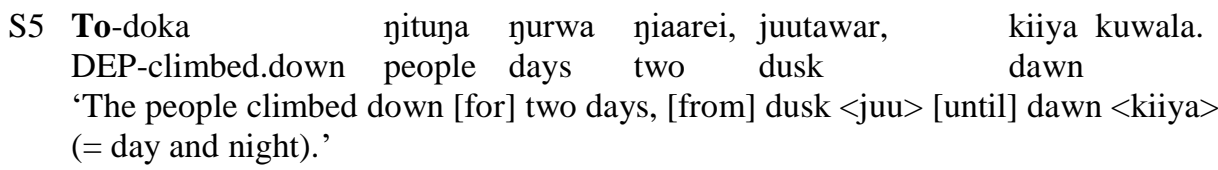

The first part of sentence (S1) Bee kolono nuwani, na eyakatare yituya kidyaama 'It is said long ago, when people were in heaven' sets the scene for the narrative, the main verb bee 'it is said' is a frozen form of the verb bala 'to say' which developed into an opening formula. That the time frame for the events is set in the past is underlined through the adverbials kolono nuwani 'long ago'. The clause represents the setting of a narrative and opens up the contextual information that all people were in heaven, and raises expectations of what is going to happen to them. The medial clause tatam $\underline{u}$ Nakuju 'God thought' which carries the dependency marker ta- has the same time frame as that of the controlling clause which points to the distant past. In the expression abu Nakuju 'God came' in (S2) the person agreement prefix $a$ - of $a b u$ 'he came' includes the fused past tense marker $a$-. This sentence serves as the controlling clause of a long chain. All other events following $a b u$, i.e. those that carry the to-/ $k i$ - markers, take place in the past, copying the past marker of the initial clause into the entire chain (taken from Schröder 2013: 33):

$$
\begin{aligned}
& \text { ta-tamú } \\
& \text { to-limoki jikaniti } \\
& \text { tem }{ }^{12} \\
& \text { to-woyiu Napurukucu } \\
& \text { to-woi } \\
& \text { ki-yooliwunoe nai yituna } \\
& \text { ki-bitibitiuni kopo } \\
& \text { to-doka yituna yurwa yiaarei }
\end{aligned}
$$

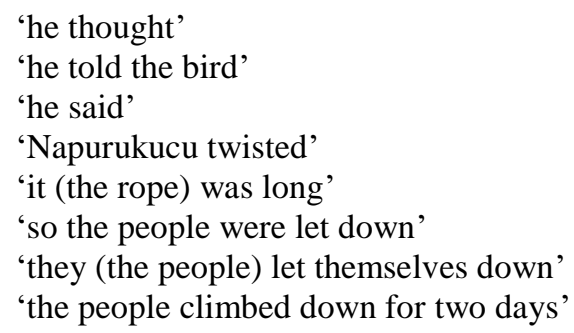

It is widely accepted that narratives are built on successions of events that take place in the past, so the above chain represents the foreground information of one paragraph.

On the other hand, if a verb carries the normal tense-aspect markers as described in conjunction with examples (2a-b) and (3) and if there is no to-/ki- marking, the hearer infers that that information does not contribute to the sequential order of the events but clarifies, explains or supports the sequence of events and is more backgrounded. In this way the relative clause (S2) nibe Napurukucu 'which was called Napurukucu', which introduces one of the main characters of the story, is backgrounded.

Next, let us consider a procedural text. Like narrative texts, which are based on a progression of events, procedural texts also involve progression, but while narratives tell what someone did, procedural texts describe how it is (normally) done. ${ }^{13}$ A narrative is fundamentally descriptive in nature, whereas a procedural text is more prescriptive. While succession of events or processes is a common feature of both narrative and procedural texts, the two texts substantially differ in terms of participants. A narrative has a +participant setting and the procedural has a participant parameter. ${ }^{14}$ The following Toposa procedural text describes how a woman gives birth, and the activities and customs that surround it (taken from M. Schröder 2010: 113):

\footnotetext{
${ }^{12}$ In this verb, the dependent marker $t$ - is fused with the root.

13 This kind of discourse is found in manuals, prescriptions of recipes and any kind of rule book.

${ }^{14}$ C.f. Longacre's text typology (Longacre \& Hwang 2012: 37).
} 


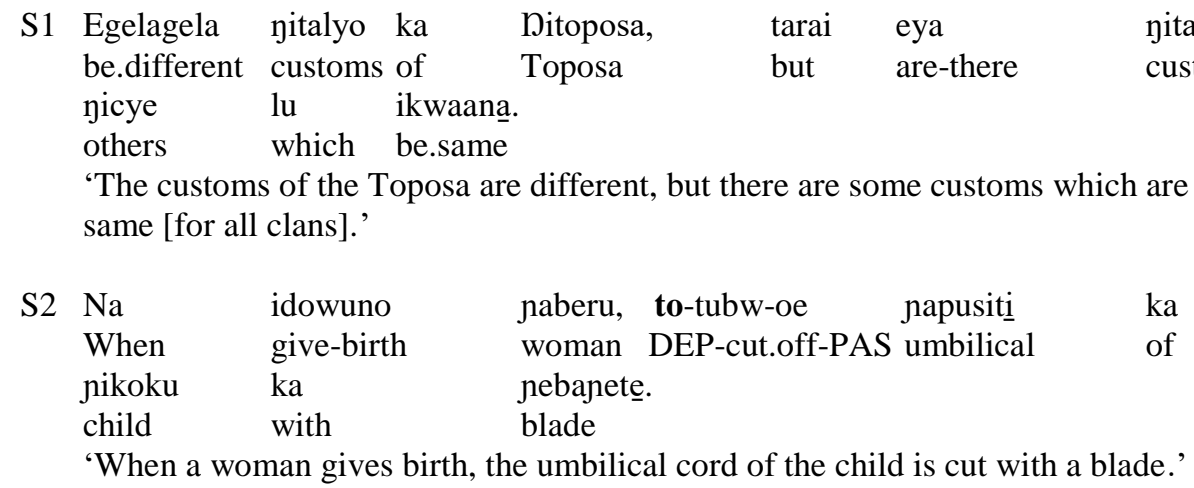

S3 Ki-lomakin-ae nai naberu kai. DEP-put.into-PAS then woman house 'The woman is put into a house.'

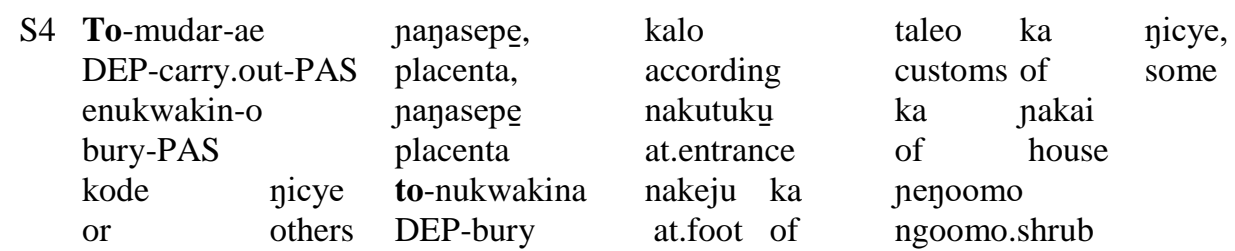
'The placenta is carried outside, according to some customs the placenta is buried at the entrance of the house or at the foot of (= under) a ngoomo-shrub.'
S5 Ki-booyi naberu kalo kai tani ecakuni napusiti ka jikoku. DEP-stay woman inside house until fall.off umbilical of child 'The woman stays in the house until the umbilical cord of the child falls off.'

In this text the dependency markers signal the progression of processes, not of narrated events. However, in the same way as in narratives, the chains also adopt the tense of the controlling

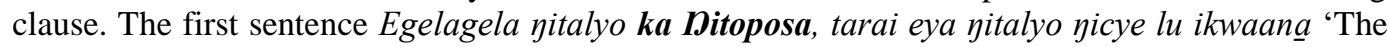
customs of the Toposa are different, but there are some which are the same' is expressed in the present tense, and so is the beginning of the second clause Na idowuno naberu 'when a woman gives birth', whereas all medial clauses follow the tense ${ }^{15}$ operator of the controlling clauses and adopt present tense, and carry the dependency marker to-/ ki- for clause-chaining (discussed in Schröder 2013: 34):

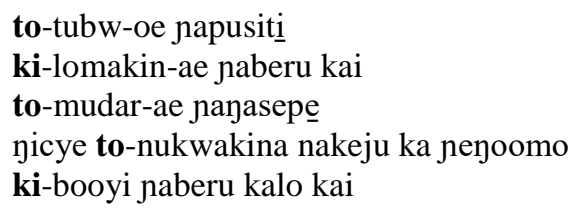

\begin{abstract}
'the umbilical cord is cut' 'the woman is put in house' 'the placenta is carried outside' 'others bury it under a ngoomo-shrub' 'the woman stays in the house'
\end{abstract}

The above chain of progression represents the foreground information of the paragraph. Note that both verbs in (S1) i.e. egelagela 'they are different', and eya 'they are', and the verb idowuno 'she gives birth' in (S2) are verbs that show the normal tense marking, as described in

\footnotetext{
${ }^{15}$ In procedural texts no aspect marking is employed, because another feature of procedural texts is the use of the passive marked with the suffix -ae and -oe as seen in example (7).
} 
example (2a-b) and (3) above. Since these verbs do not carry to-/ki- marking, they contain background information: they set the scene for the description of the processes of childbirth.

Inside the chain of salient processes of childbirth, a statement is made about the disposal of the placenta: enukwakino nayasepe nakutuku ka nakai 'the placenta is buried at the entrance of the house', no foreground indicator appears in this comment. (Why this sentence does not carry the foreground marker to-/ $\mathrm{ki}$ - will be explained in section 3).

My final example comes from a descriptive-expository text. This type is neither agentoriented, no does it have a progression of events, in effect it describes how people [normally] do $i t .{ }^{16}$ Our example describes the ritual of initiation among the Toposa, and it uses present tense (M. Schröder 2010: 114):

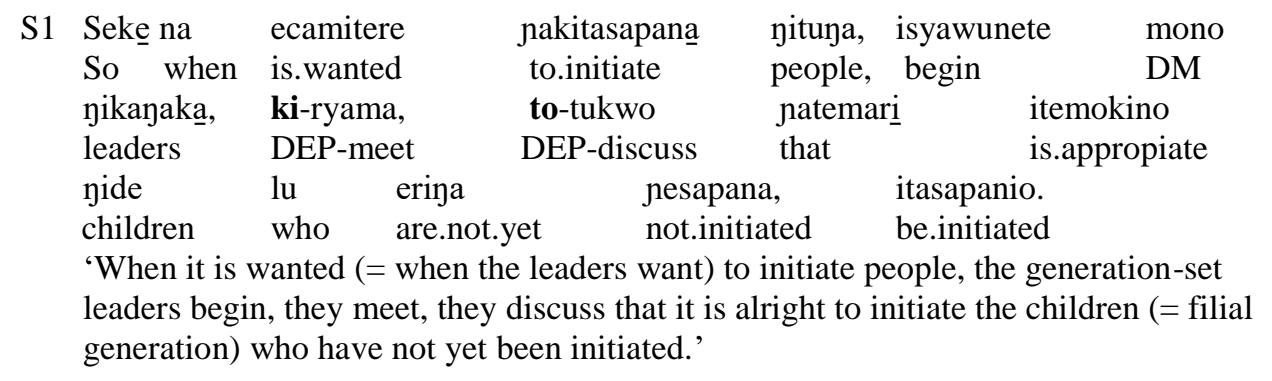

S2 To-sewutu nai nitooni ni edikino erawuni nekayani ka nikasapanaka. DEP-select then person who will become leader of initiates 'They select a person who will become generation-set leader of the initiates.'

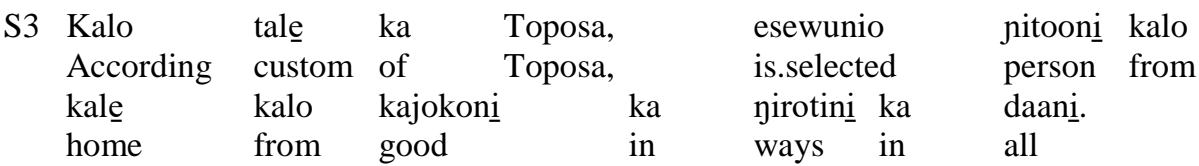

'According to the sacred custom of initiation a person from a good family in every way is selected.'

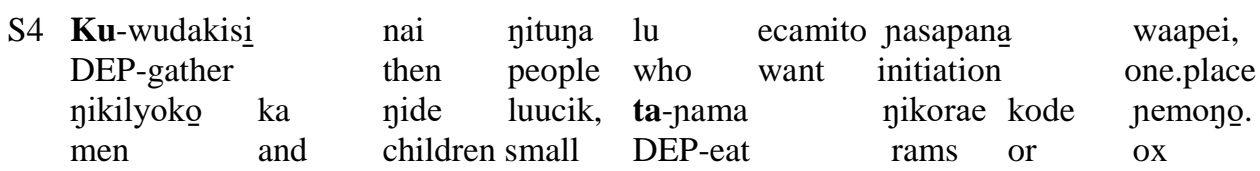

'The people who want to be initiated gather in one place, the men and the children [of the new set], they eat goats or an ox.'

S5 Narumworete yuna, to-loto nai to-pero naperiti. end this, DEP-go then DEP-sleep in.sleeping.ground '[After] the end of that they then go to sleep in the [separate] sleeping-ground.'
S6 Ani
iwalari, ki-ryewutu
yaberu kece
tya
taityekece
When
dawns, DEP-grind
wives their and
their.mothers

\footnotetext{
${ }^{16}$ One reviewer raised the question whether procedural (texts that deal with how it is done) and descriptiveexpository texts (texts that describe how people normally do it) can be collapsed into one category. I maintain the position that they are distinct. Procedural texts are prescriptive in nature, they are like rule books, they represent a collection of rules that lead to a completion of a product like the recipe for a cake. Descriptiveexpository texts are descriptive in nature and describe what people normally do from an observational point of view.
} 
ka pide yatapae.

of children porridge

'When it dawns, the wives and the mothers of the children grind [and bring] porridges.'

S7 $\mathrm{Na}$

When approach

ta-mawutu nituna yuu

DEP-praise

people three

yaberu naperiti, $\quad$ ku-waasi

jikilyoko,

women sleeping.ground DEP-sing

men

nepite

yolo

or

yooywono,

to-kusete

narupepe,

custom

that

DEP-praise

four

DEP-blow.SIM horn

'When the women approach the sleeping-ground, the men sing [antiphonally], they

praise three or four people [so they come out and perform a dance], while they are

blowing a horn, according to custom the women also sing praises of their cows.'

S8 Ku-waakisi nai yaberu namuja kopo.

DEP-put then women foods down

'Then the women put the foods on the ground.'

S9 To-sewun-ae nai nituna lu ekorakinete nakumuju lotuna.

DEP-select-PAS then people who distribute food to.people

'Then people are selected who distribute the food to the people.'

This text describes the events that happen during the initiation of young men. The chain adopts the present tense from the controlling clause. The first part of the sentence Seke na ecamitere nakitasapana yituja, isyawunete mono jikayaka, ... 'When initiation of the people is wanted, then the generation-set leaders begin,' opens the expository text and is the controlling syntactic clause in present tense and imperfective aspect. The following clauses describe the initiation process and they are all marked with the clause chain indicators to-/ki- (see also Schröder 2013: 37):

$$
\begin{aligned}
& \text { ki-ryama } \\
& \text { to-tukwo } \\
& \text { to-sewutu jitooni } \\
& \text { ku-wudakisi nituna } \\
& \text { ta-nama yikorae kode nemono } \\
& \text { ki-ryewutu yaberu yatapae } \\
& \text { ku-waasi nikilyoko } \\
& \text { ta-mawutu yituna yuuni kode yoonwono } \\
& \text { to-kusete narupepe } \\
& \text { ku-wanakisi yaberu day yaatuku kecẹ. } \\
& \text { ku-waakisi yaberu yamuja kopo. } \\
& \text { to-sewunae nituna }
\end{aligned}
$$

\author{
'they (the leaders) meet' \\ 'they discuss' \\ 'they select a person' \\ 'the people gather' \\ 'they eat goats or an ox' \\ 'the wives bring porridge' \\ 'the men sing' \\ 'they praise three or four people' \\ 'while they are blowing a horn' \\ 'the women also praise their cows' \\ 'women put food on the ground' \\ 'people are selected'
}

As with the other genres considered before, also here in this descriptive text all chained clauses are the ones that contain foregrounded information. Embedded in the chain there are a few clauses showing background information: The sentence (S3) Kalo tale ka Toposa, esewunio nitooni kalo kale kalo kajokoni 'according to the sacred custom of the Toposa, a person from a good family is selected' clarifies who one of the main actors is in the initiation process. The following clauses in (S1) lu eriya nesapana, itasapanio '[children] who are not yet initiated, are initiated', and in (S4) lu ecamito nasapana'[people] who want initiation' are both backgrounded and serve as clarifications regarding the actors in the initiation process. (S6) Ani iwalari 'when it dawns' sets the 
stage for the next phase of the initiation process. All these clauses (which exhibit normal tense aspect marking) are selected as background information by the hearer. ${ }^{17}$

In Toposa clause-chaining is not genre-specific, it can occur beyond the narrative text which is the most frequent genre that employs clause-chaining (c.f. Dooley 2010:4).

After having established how the features of clause-chaining structure the narrative, procedural and descriptive-expository texts a further question has to be answered, what is the scope of the clause-chaining features in Toposa?

\section{The clause chaining model}

It is not uncommon that clause chains to a certain extent may contain subordinate clauses although these are typically considered background information, and thus this behavior of some clausechaining languages confuses the fundamental distinction discussed above. In any case, a language has to be tested whether subordinated clauses can appear with the medial marker, and if so, which ones and how the clause chaining effect in subordinated clauses effects the overall model of coordinative and subordinative sentences known from English.

Longacre (1996: 285-286) observed that language could either fall under the 'co-ranking' or 'chaining model'. The co-ranking model groups clauses such as time, condition, concession, purpose, reason etc. as subordinate clauses. The chaining model however cannot allow two independent verb forms following each other but forces the chaining effect to dominate the structure of discourse. Following this suggestion Toposa falls into the chaining model. In this model the structures that follow the initial inflected opening clause are reduced to structures that are marked with the clause chaining marker. ${ }^{18}$ Thus, the division of the clause types is organised around the overall foreground and background effect. The clause types that such a model employs are independent, medial clauses and as a third category subordinated clauses with finite verbs. Those clauses are found in clause skipping. To start the argument, the next section will demonstrate the clauses known as subordinate clauses that use the medial verb form.

3.1. Subordinative clauses with medial verbs. The following subordinative clauses are integrated into the chains and use medial verb forms. Such clauses are purpose and means-result clauses.

In Toposa, the purpose clause employs the medial verbal form. If kotere occurs with a medial verb, it introduces a purpose clause and its meaning is introduced with the semantic connection kotere 'in order to', see the following example:

$\begin{array}{lll}\text {..ta-tyakae } & \text { nai } \quad \text { kalo } & \text { kidini } \\ \text { DEP-divide } & \text { DIS from } & \text { middle } \\ \text { kotere } & \text { ku-waae } & \text { nepeewae } \\ \text { in.order.to } & \text { DEP-store } & \text { one part } \\ \text { 'It was divided in the middle (= into two parts) in order to store one part.' }\end{array}$

It is also possible that kotere introduces semantically a means-result relationship. In that case a medial verb has to be used, see the following example:

$\begin{array}{llll}\text { To-sewutu } & \text { nelapa } & \text { kode } & \text { nekaru, } \\ \text { DEP-choose.VEN/PL } & \text { month } & \text { or } & \text { year }\end{array}$

\footnotetext{
${ }^{17}$ This observation is confirmed by Unger (2006) for narrative texts. He states that there is a correlation between the expectation of listeners to understand events in narratives as their most relevant information through the encoding of tense and aspect (p. 306), but that this relationship has rarely been reported for nonnarrative types of text (Unger 2011: 110). However, the two texts in (10) and (12) above show that the Toposa markers are not confined to narratives but are also found in procedural and expository-descriptive texts.

${ }^{18}$ Longacre (1996: 286) also calls this verbs 'consecutive' verb.
} 


\begin{abstract}
kotere ku-waruneta nituna niboro ka nakidamadama. so that DEP-look.VEN/INS/PL people things of dance

'They choose a month or a year, so that people will look for the things of the dance.'
\end{abstract}

The idea that subordination clauses headed by conjunctions could be part of the chain was rejected by Myhill \& Hibiya in their clause-chaining definition (1988: 363). They specifically stated that clauses headed by conjunctions cannot constitute chains. This statement was falsified through example (14) and (15) in Toposa. Note that the above two examples show that kotere 'in order to/so that' is polysemous and context has been used to disambiguate the meaning of the clauses.

The coordinative contrast relationship is expressed by the conjunction tarai 'but' which can occur with and without medial verbs. The narrator can decide which contrast clause is foreground or background information. Consider tarai with a medial verb first:
Ki-bi
Lobela
Lolemumoe, tarai
to-pege
Lolemumoe
jiki.
DEP-ask Lobela Lolemumoe but DEP-deny Lolemumoe strictly

'Lobela interrogated Lolemumoe, but Lolemumoe denied [it] strictly.'

Note how tarai here heads an event clause with an event verb that is part of the foreground event line in a narrative. If however tarai is used with an inflected verb, the verb is a non-event verb that places the sentence in the background information span also taken from a narrative text:

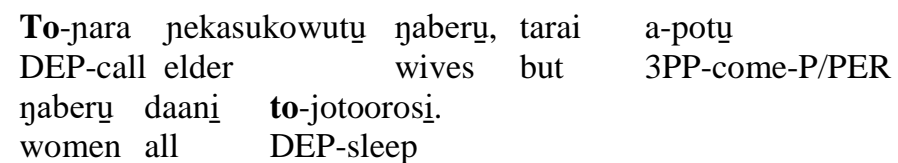

'The old man called [his] wives, but all the women had come [discourse] [and] had fallen asleep.'

The tarai clause with the inflected verb describes an anterior event and represents background information.

The coordinative additive relationship also employs the medial clause marking and no conjunctions are used. The sentence construction consists of a controlling clause and one or two (at most) medial clauses:
A-bu
to-osiki
nakimar
sementiks, ta-lakari nakilo.
3P-came
DEP-give.up reading
semantics, DEP-happy more.than
'He gave up studying semantics and felt much happier.'
E-bariti nekilye, to-yar-ite.
3P-rich man DEP-live-SIM
'The man is rich and (furthermore) successful.'

Note in (18) the onset $a b u$ 'he came' ${ }^{19}$ has to occur. In example (19) the suffix -ite indicates simultaneity. The second clause of example (18) can also be understood as a result of the first statement 'he felt much happier'. In example (19) the medial clause demonstrates a dependent consequential relationship. The above examples confirm Longacre's (1996: 286) observation that in the chaining model two independent clauses following each other are not permitted. The next category of clauses represents the subordinative clauses with finite verb inflection.

\footnotetext{
19 The full function of $a b u$ 'he came' occurring in texts or in single co-ordination is still under investigation.
} 
3.2 Subordinative clauses with finite verbs. In Toposa, temporal adverbial clauses and adverbial clauses with 'until', complement clauses, and reason clauses are typically not included in clause chains and occur with inflected verbs.

Toposa has temporal adverbial clauses that are introduced with $a n i$ 'when' and $n a$ 'at the time', 'whenever'. These clauses occur with fully inflected verbs, see the following examples taken out of example (5):

$$
\begin{aligned}
& \mathrm{Na} \text { e-yakatare } \quad \text { jituna kidyaama, ... } \\
& \text { when 3PP-were people above } \\
& \text { 'When there were people in heaven, ...' }
\end{aligned}
$$

The verb in the clause is fully inflected and it introduces the chains for the whole story as it is part of the introduction. The temporal clause is followed by the medial verb tatam $\underline{u}$ Nakuju (God thought), see another example with ani taken also from example (5):

$$
\begin{array}{lll}
\text {...ani e-baa-si } & \text { yurwa } & \text { apana uni, } \\
\text { when 3PP-say-IMP:PL days } & \text { up_to three } \\
\text { ku-buyakini naberu na } & \text { a-poti ... } \\
\text { DEP-eager woman who } & \text { 3PP-be_pregnant }
\end{array}
$$

'When it was almost three days, a woman that was pregnant was eager to...'

The inflected verb in the clause that starts with the conjunction ani 'when' interrupts the chain. Ani often indicates the beginning of a new paragraph. The clause chain stops before the adverbial subordinate clause with ani and at the same time this clause also starts a new chain with kubunakini naberu 'a woman was eager'. Temporal clauses are also used for discourse structuring see the session below.

The adverbial clause expressed by tani 'until', which is placed at the end or in the middle of a chain, is used with inflected verbs and typically contains background information. The following example shows the occurrence of tani in the middle of a clause chain:

$$
\begin{aligned}
& \text { Ki-syautu }{ }^{20} \text { nai ikesi ne-kere, to-sukwo kaneni } \\
& \text { DEP-begin DIS they INF-race DEP-runPL from.there } \\
& \text { tani e-nay-i Nebu nikalonani, to-nara Nebu Nakidodoko. } \\
& \text { until 3P-reach-IMP hyena far_away DEP-call hyena frog } \\
& \text { 'They began racing, they ran from there until Hyena reached far away, Hyena called } \\
& \text { Frog.' }
\end{aligned}
$$

As this example shows, the chain is not broken through the occurrence of the adverbial clause with 'until', a phenomenon that is explained in the section under clause insertion.

In some languages, clause-chaining can include conditional clauses (see Stirling 1993: 190, where an example for Amele is quoted). In Toposa, conditional clauses are generally not included in the chain and are used with inflected verbs. As the following example shows, the conditional clause often interrupts a chain to provide some background information:

\footnotetext{
${ }^{20}$ If sentences are starting with a dependent verbs, they are taken out of chains for the purpose to show certain linguistics features for example (22) demonstrates that the adverbial clause starting with tani 'until' is not used with a dependent verb.
} 


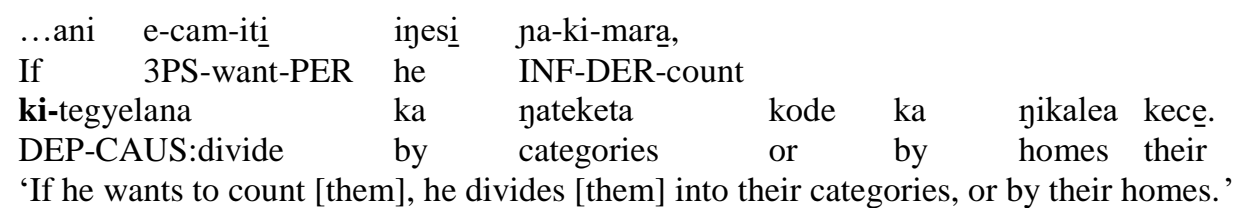

Note that the verb in the conditional clause carries a perfective suffix and the present tense meaning ${ }^{21}$ so the verb in the medial clause copies the present tense meaning.

Note further that the conjunction ani 'when' can also be used for conditional clauses with the meaning 'if'. The conditional realis will use ani only and the irrealis ani kerai.

Adverbial clauses of manner are always regarded as background information and occur with an inflected verb, as in the following example:

$\begin{array}{llllll}\text { Bee } & \text { koloyo } & \text { nacye paarani, to-rot-oki } & & \text { Nemiri, } \\ \text { It.is.said } & \text { long.ago } & \text { another day } & \text { DEP-set.out-BEN } & \text { mouse } \\ \text { to-rukwa-u } & \text { Nenatunu } & \text { e-per-i } & \text { kana dui } & \text { kene. } & \\ \text { DEP-find-ALL } & \text { lion } & \text { 3P-sleep-IMP } & \text { in } \text { hole his } & \end{array}$

'It is said that one day Mouse set out, he found Lion sleeping in his hole.'

The manner clause eperi kana dui keye 'sleeping in his hole' has an inflected verb.

Toposa has a conjunction kotere which can be used with both, inflected and medial verbs. In case kotere occurs with inflected verbs its meaning is 'because' and it represents a reason-result sentence in a chain, see the following example:

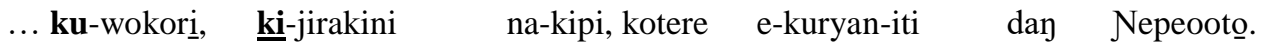

$$
\begin{aligned}
& \text { DEP-run DEP-slip water because 3P-afraid-PER also hunting-dog } \\
& \text { 'He runs away, slips into the water, because he is also afraid of hunting dog.' }
\end{aligned}
$$

The subordinative clause introduced by kotere has an inflected verb, following two medial verbs and is often placed at the end of the sentence construction. The occurrence of the medial verb indicates to the hearer that the clause is not providing the purpose for the action of the previous clause, but it is semantically a reason-result clause, compare with example (14).

Complement clauses occur with fully inflected verbs and not with medial verbs.

$$
\begin{array}{cccc}
\text {... ki-boyii ca, ta-anu } & \text { Kwee natemari } & \text { e-twaniti } & \text { itekene } \\
\text { DEP-sit DIS } & \text { DEP-see } & \text { Jackal that } & \text { 3P-died-PER mother-his } \\
\text { 'He (= Jackal) sat (= waited), Jackal saw that his mother had died.' } &
\end{array}
$$

It is not uncommon to have negation excluded from the clause-chaining devices, because they indicate background information (Longacre \& Hwang 2012: 185), see the following example:

$$
\begin{aligned}
& \text { Ku-cwa-ki nituya naanuni nayololo nina, } \\
& \text { DEP-send-BEN people to.find river that } \\
& \text { tarai n-e-dolo yituna yulu, ta-tamu nabo Lokoliniro ... } \\
& \text { but NEG-3PP-reach people these DEP-think again Lokoliniro } \\
& \text { 'He [Lokolingiro] sent people to find that river, but these people did not reach [it]. Also, } \\
& \text { Lokolingiro thought ...' }
\end{aligned}
$$

\footnotetext{
${ }^{21}$ There is a small group of verbs in Toposa that carry perfective marking but really have present continuous meaning, possibly in the sense of 'has started to'.
} 
In example (27) the negative clause tarai nedolo yituya yulu 'but these people did not reach [it]' interrupts the chain that continues with tatamu nabo Lokoliniro 'also, Lokolingiro thought'. The negation clause is not used with the medial verb. Negative clauses are typically regarded as background information and categorized as collateral information (Grimes 1975, Longacre \& Hwang 2012:18).

3.3 Clause insertion. There is an intriguing phenomenon in the discourse structuring of some clause-chaining languages in that they allow a clause with a regular verb inflection to be inserted into a chain without breaking it. This clause insertion is not a new phenomenon for clause-chaining languages. Lesley refers to this form of insertion as "clause skipping" (1993: 18-20).

Toposa allows two types of clauses to be inserted in this way, all subordinative clauses with finite verb inflections and metarepresentations.

The following example presents an embedded clause with regular verb inflection as an example of all the other clauses discussed above that do not break the chain (data taken from $\mathrm{M}$. Schröder 2010: 48):

$$
\begin{aligned}
& \text { Ani e-jeketa yakile ka naate, ta-ratarata Kwee Nebu, } \\
& \text { When 3P-become.good milk of cow DEP-cheat:INT jackal hyena } \\
& \text { to-lepuuni ca naate, to-noba nakile, } \\
& \text { DEP-milk:HAB:SIM DIS cow DEP-drink.up milk } \\
& \text { ani i-don-i negoototo, to-lemu pacoto, ki-yatakinea ... } \\
& \text { when 3P-remain-IMP:PAST foam DEP-take urine DEP-add } \\
& \text { 'When the milk of the cow had become good, Jackal cheated [intensive] Hyena, he } \\
& \text { continually milked the cow, he drank up the milk, when [only] foam remained, he took } \\
& \text { urine, he added [that }], \ldots \text { ' }
\end{aligned}
$$

Into this chain of eight clauses (only five are shown), the clause ani idoni negoototo 'when [only] foam remained' has been inserted without breaking the chain: the paragraph continues with to- $/ \mathrm{ki}$ - forms, which are still dependent on the first controlling clause of the string of clauses.

In terms of the foreground-background distinction the embedded clause can be regarded as background information that clarifies the logical succession of the events in the chain. In example (28) the skipped clause explains when hyena added urine to the milk.

Chains can also have metarepresentations inserted. Metarepresentations constitute thoughts about known customs, sayings or citations. They a shared implicit background information in the mind of the narrator and listener and they are made explicit for the explanation of the succession of the actions that taken place. In the following example the metarepresentation refers to a custom that regulates the burying of the placenta (this is the same as S4 in example (10) above):

$\begin{array}{llllll}\text { To-mudarae } & \text { najasepe, } & \text { kalo } & \text { taleo ka jicye, } \\ \text { DEP-carry.out } & \text { placenta, } & \text { according } & \text { customs of } & \text { some } \\ \text { enukwakino } & \text { nayasepe } & \text { nakutuku } & \text { ka jakai } & \\ \text { bury-PAS } & \text { placenta } & \text { at.entrance } & \text { of house } & \\ \text { kode yicye } & \text { to-nukwakina } & \text { nakeju ka } & \text { neyoomo. } & \\ \text { or others } & \text { DEP-bury } & \text { at.foot of } & \text { ngoomo.shrub } & \end{array}$

'The placenta is carried outside, according to some customs the placenta is buried at the entrance of the house or at the foot of (= under) a ngoomo-shrub.'

Inside the chain of the salient processes of childbirth, a statement is inserted about the disposal of the placenta: kalo taleo ka yicye, enukwakino nayasepe nakutuku ka nakai 'according to the customs of some, the placenta is buried at the entrance of the house'. The reason why this embedded comment does not carry any chaining marker to-/ki- is that it constitutes a metarepresentation which serves as a backgrounded explanation for why the placenta is buried at 
the entrance of the house. The burying is not only a random process but has to follow clearly defined procedures. The next clause resumes the previous chain, as is indicated by the verb in yicye tonukwakina 'others bury it', i.e. the metarepresentational clause is inserted into the chain without breaking it.

Metarepresentations of this type do not only occur in narrative and procedural texts but also in expository ones. For example, the following contains another metarepresentation that explains a custom (I repeat here only S2, S3 and the beginning of S4 from (9) above):

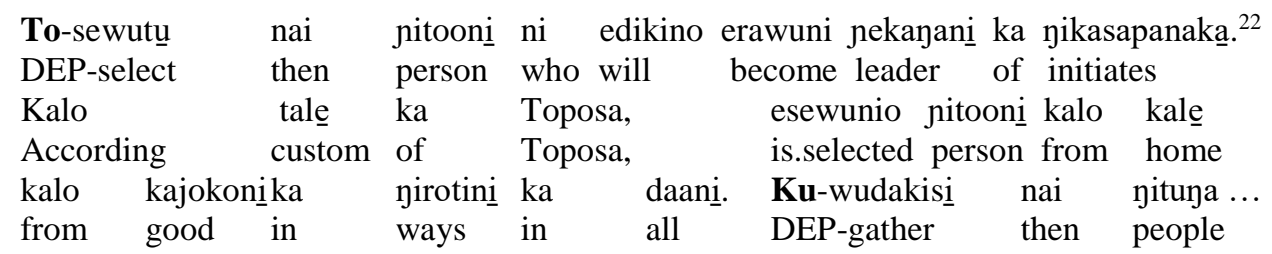

'They select a person who will become generation-set leader of the initiates. According to the sacred custom of initiation a person from a good family in every way is selected.

Then the people collect ...'

The inserted clause with the verb esewunio 'he is selected' shows no to-/ki- marking. Pragmatically, it is a metarepresentation that explains the principle that guides the selection of a ceremonial leader, which is underscored by the phrase 'according to the sacred custom of initiation'. In terms of discourse structure, this clause provides additional background information.

In summary one can say the inserted clauses serve as background information to explain, clarify or comment on the actions in narrative clauses, the procedures in procedural texts or the descriptions in expository texts.

One reason for clause skipping can be explained with the principle of economy. If the narrator thinks an explanation for the action, procedure or description is needed; he inserts an inflected clause that effectively ignores the structure of the chain. In terms of language production, the insertion of background information is very efficient. Schröder (2013: 39) points out that the cognitive processing of the foreground markers $t o / k i$ have developed into pragmatic routines that guide the hearer to comprehend the foreground information effortless. Similarly, the absence of the foreground marker guides the hearer to access and interpret explanations and comments on the foreground information.

The next question deals with how the co-reference is handled in Toposa clause-chaining, which is either a choice between switch-reference or pivot constraint.

\section{The co-referential pivot in Toposa clause-chaining}

Switch-reference are known to accompany clause-chaining languages as stated by Roberts (1988: 62), Stirling (1993: 14), Dooley (2010: 5), Huang (2000: 289-290), and Longacre \& Hwang (2012: 9). Toposa, however, works on a mixed S/A-S/O pivot constraint and does not employ switch reference for tracking referents in the chains.

If languages have a S/A pivot constrain, ${ }^{23}$ the coreferential NPs are found in S or A functions. In order to maintain the S/A constraint an NP in O function has to be passivized to satisfy this pivot. Languages with S/O pivot, however, operate with the corefential NPs of S and O. In order to keep the constraint, a NP that is in A function, has to be antipassivized. 2015a: 235):

The coreferentiality in Toposa has two major conditions (discussed previously in Schröder

\footnotetext{
${ }^{22}$ As in S5 in example (2), the relative clause is subordinate and not part of the chain.

${ }^{23}$ When talking about S/A or S/O pivots, $\mathrm{S}$ refers to the subject of the intransitive clause, A to the subject of the transitive clause and $\mathrm{O}$ to the object of the transitive clause.
} 
1. Formal condition: The coreferent is marked on the verb as an integrated subject pronoun either by an overt morpheme for first person singular and plural, or by a zero morpheme for second and third person singular and plural.

2. Functional condition: The interpretation of argument coreferentiality between clauses works on a mixed S/A-S/O pivot.

How the formal and functional conditions of Toposa coreferentiality function will be demonstrated in the next section.

4.1 The S/A pivot. This section shall demonstrate the S/A pivot relationship between coreferential arguments. Consider example (31) which repeats the first two sentences from example (8):

$\begin{array}{llllrr}\text { A-bu Nakuju, to-limoki } & \text { nikaniti } & \text { nitikawosoni } & \text { nibe } & \text { Napurukucu, } \\ \text { 3P-cameGod, DEP-told } & \text { bird } & \text { very.clever } & \text { who.called } & \text { Napurukucu } \\ \text { tem, "To-woyiu } & \text { nawuno, } & \text { kotere } & \text { ki-yooliyorotori nituna } & \text { kopo." } \\ \text { DEP:said IV-twist rope } & \text { in.order.to DEP-take } & \text { people } & \text { down }\end{array}$

'God came, he told a very clever bird whose name was called Napurukucu (= Orange

Starling), he said, «Twist a rope in order to take people down.'

Consider also the following sentences in example (32) from an expository-descriptive text (which repeats three sentences from example (12)):

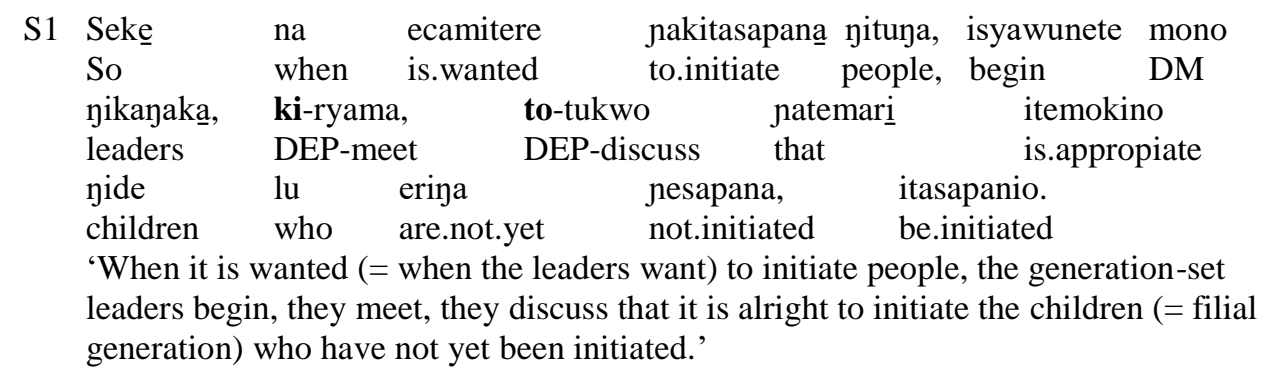
S2 Ku-wudakisi nai nituna lu ecamito nasapana wapei, DEP-gather then people who want initiation one.place jikilyoko ka jide luucikị, ta-nama yikorae kode nemono. men and children small DEP-eat rams or ox 'The people who want to be initiated gather in one place, the men and the children [of the new set], they eat goats or an ox.'

S3 Narumworete yuna, to-loto nai to-pero naperiti. end this DEP-go then DEP-sleep in.sleeping.ground '[After] the end of that they then go to sleep in the [separate] sleeping-ground.'

The sentence in example (31) combines the $\mathrm{S}$ of the intransitive controlling clause $A b u$ Nakuju 'God came' with a coreferential A of the first chained clause tolimoki nikaniti 'he told the bird' with another coreferential A of the second chained clause tem 'he said'. In example (32) in sentence $\mathrm{S} 1$ a $\mathrm{S}$ is found in the controlling clause isyawunete mono yikayaka 'the leaders begin' and this $\mathrm{S}$ has the $\mathrm{S}$ of the intransitive clause as coreferent and the coreferential A of a transitive clause

\footnotetext{
${ }^{24}$ Note that the prefix $\mathrm{To}^{-}$- in this example is an imperative marker that has the same form as the dependence marker.
} 
kiryama, ${ }^{25}$ totukwo natemari itemokino 'they meet, they discuss that it is appropriate ...'. Clauses in S2/S3 of example (32) link the S with a co-referential A, with a co-referential S and a co-referential $\mathrm{S}$ in kuwudakisi nai yituya ..., tanama jikorae kode nemoyo, ..., toloto nai, topero naperiti 'the people gather..., they eat goats or an ox, ... they go and they sleep in the sleeping-ground'.

4.2 The S/O pivot. The S/O pivot restricts the co-referentiality to either $\mathrm{S}$ or $\mathrm{O}$ in subsequent clauses. The S/O pivot linkage in Toposa is due to passive constructions that have the $\mathrm{S}$ constituent construction of the intransitive passive clause marked as accusative, like the object marking of a transitive clause (as also in most Southern Nilotic languages). Consider the following:

$$
\begin{aligned}
& \text { a. È-kèr-é-tè } \quad \text { yá-àtùk. } \\
& \text { 3P-run-IMP-PL F/PL-cow/NOM } \\
& \text { 'The cows are running.' }
\end{aligned}
$$
b. İ-dés-ì né-kílè yá-átûk. 3P-beat-IMP M/SG-man/NOM F/PL-cows/ACC

'The man is beating the cows.'

$$
\begin{aligned}
& \text { c. İ -dés-ít-àè yá-átûk. }{ }^{26} \\
& \text { 3P-beat-IMP-PAS F/PL-cows/ACC }
\end{aligned}
$$

'The cows are being beaten or somebody beats the cows. ${ }^{27}$,

All these constructions are impersonal passive constructions. In (33c) the nominative tone marking which would be HLL for yáàtùk 'cows' as in (33a) would be expected, rather, it bears the accusative tone marking HHF gáátûk as in (33b). ${ }^{28}$ In other words, in Toposa the S of the intransitive impersonal constructions bears the accusative tone marking and it is morphologically marked in the same way as the object of the transitive clause (Schröder 2008: 58-59). The impersonal passive construction in some Eastern Nilotic languages (Toposa, Turkana and Maasai) and Southern Nilotic languages (Tugen, Kipsigis, Nandi etc.) incited debate whether this construction is a real passive construction, or an impersonal third person construction (Schröder 2015b). If the latter view is accepted, (33c) would best be translated as 'somebody beats the cows'. Irrespective of how the construction is interpreted, the single lexical argument of the impersonal construction renders accusative case marking and constrains the occurrence to either an $\mathrm{S}$ or another $\mathrm{O}$ in conjoined sentences, see the following example taken from M. Schröder (2010: 6):

$$
\begin{aligned}
& \text {... ki-yooliwun-oe nai nituya, ki-bitibitiuni } \\
& \text { DEP-let-down-PAS so people DEP-let.themselves down, women } \\
& \text { ka yide tya nikecekilyoko. } \\
& \text { and children and husband-theirs } \\
& \text { 'The people were let down, they let themselves down, the women and children and } \\
& \text { their husbands.' }
\end{aligned}
$$

\footnotetext{
${ }^{25}$ Note that in Toposa the verb kiryama 'meet' is intransitive: kiryama ka nikoku 'he met with [the] child'.

${ }^{26}$ Take note of the personal pronoun marker $i$ in $(28 \mathrm{~b})$ and (28c). The $i$ - is the same for the third person singular and plural. Regarding passive: Toposa has an impersonal construction marked by passive suffixes $-0 \sim-a e \sim$ oe.

${ }^{27}$ The difference between the person agreement third person plural prefix $e$ - of examples (33a) and the $i$ - of (33c) is due to different verb classes. The $i$ - occurs with KI-class verbs and the $e$ - with TO-class verbs.

${ }^{28}$ Note that the accusative tone pattern of yáátûk 'cows' is HHF only before pause and HHL (gáátùk) elsewhere.
} 
In (34) the O yituya 'people' of the passive clause, coreferences the $\mathrm{S}$ of the intransitive reflexive clause kibitibitiuni 'they let themselves down'.

See another example where the S/O pivot constraint contributes to the disambiguation of meaning (data taken from M. Schröder 2010: 8):

$\begin{array}{lllll}\text { S1 To-limokisi nai } & \text { Dimoru talokaatekece, } & \text { temasi, } \\ \text { DEP-tell } & \text { then } & \text { Stones } & \text { brothers.theirs } & \text { DEP:say } \\ \text { "Kapesi } & \text { ta-ana } & \text { jibarene } & \text { kana wiye.". } \\ \text { IV-go } & \text { DEP-look } & \text { cattle } & \text { in } & \text { cattle-camps }\end{array}$

'Those Stones [generation-set] said to their brothers, "Go and look after the cattle in the cattle-camps!"
S2 Ki-det-ae
ka jalita, ki-reye-e,
temar-ae ...
DEP-beat-PAS with sticks DEP-chase-PAS DEP:say-PAS
'They were beaten with sticks, and were chased, and it was said ...

In (35) the common $\mathrm{O}$ talokaatekece 'their brothers' coreferences another $\mathrm{O}$ in $\mathrm{S} 2$ Kidetae $k a$ yalita 'they were beaten with sticks', and another $\mathrm{O}$ in another impersonal clause kirenee 'they were chased'. The underlying S/O pivot contributes to disambiguate the coreferentiality between 'they' in S2. Because of the S/O pivot in passive clauses 'they' coreferences to 'the brothers' and not 'the stones'. If the S/A pivot would be applied it would be not clear whether the subject Dimor $\underline{u}$ 'the stones' or the object talokaatekece 'their brothers', introduced in S1 as A and $\mathrm{O}$, are coreferenced in $\mathrm{S} 2$ as the ones that get beaten.

However, in other constructions, where the impersonal does not occur, the S/O pivot must also apply. As the constraint requires, in such a case the $\mathrm{S}$ of an intransitive clause or the $\mathrm{O}$ of another transitive clause have to be coreferenced, as the following example shows (taken from M. Schröder 2010: 6):
To-woyiu nai Napurukucu
japutu
natikaanikani, to-woi ${ }^{29}$
loowoi.
DEP-twisted so Napurukucu tendon-string which.strong DEP-long very
'So Napurukucu twisted a strong tendon-string, it was very long.'

In example (36) the $\mathrm{O}$ of the transitive clause naputu natikaanikani 'a very strong tendonstring' is the common argument between the two clauses and it is coreferential with the $\mathrm{S}$ of the descriptive clause towoi loowoi 'it was very long'.

Another construction that demonstrates this $\mathrm{S} / \mathrm{O}$ pivot is the following example (taken from M. Schröder 2010: 15):

$$
\begin{array}{cccc}
\ldots \text { ku-wara Lokoliniro ka } & \text { jikeetuna } & \text { nadokari lobooto, to-twonikini. }{ }^{30} \\
\text { DEP-look Lokoliniro and } & \text { people.his } & \text { climbing to.camp DEP-difficult } \\
\text { 'Lokolingiro and his people searched [where] to climb to the camp, [but] it was difficult.' }
\end{array}
$$

In example (37) the $\mathrm{S}$ of the descriptive clause totwonikini 'it was difficult' references the object nadokari lobooto 'the climbing to the camp'. ${ }^{31}$

\footnotetext{
${ }^{29}$ Note that towoi 'it was long' is a stative verb.

${ }^{30}$ Note that the verb totwonikini is also a stative verb.

${ }^{31}$ In a S/A pivot system as in English the two sentences had syntactically to be changed into the following constructions: the second conjoined clause would have to change into a relative clause like 'Lokolingiro and his people looked [where] to climb to the camp, [but] which was difficult'; or the subject would have to be repeated; the clause could not just be conjoined as in 'Lokolingiro and his people looked [where] to climb to the camp, [but] this climbing was difficult.'
} 


\section{Discourse structuring}

If a language employs clause-chaining as a discourse function, this has serious implications for the overall discourse structuring, as we shall see in the following.

One question that arises is what principles govern the formation of chains, i.e. what syntactic or semantic factors may cause clause chains to terminate and new ones to begin. Dooley offers several possible factors (2010:14-15): causal event groupings, discourse units like a paragraph or an episode, topic chains, or any combination of the above.

In all three genres I have considered above, the length of clause chains is discourse-related, in that each chain spans a whole narrative unit. The clause chain breaks when a new paragraph starts, usually marked by the verb $a b u$ 'he came' whenever it has a discourse function, or by temporal clauses with na or ani 'when, whenever'. The first example is the same as $\mathrm{S} 2$ in example (8) above. This is the beginning of a long chain:
Abu Nakujụ,
to-limoki
nikaniti nitikawosoni
nibe
Napurukucu, came God, DEP-told bird very.clever who.called Napurukucu tem, "To-woyiu nawuno, kotere ki-yooliyorotori nituna kopo.." DEP:said IV-twist rope in.order.to IV-take people down 'God came, he told a very clever bird whose name was called Napurukucu (= Orange Starling), he said, "Twist a rope in order to take people down.",

The paragraph consists of eight chained clauses, as shown in (9), and closes before the next paragraph opens with ani ebaasi yurwa apana uni 'when it was almost three days':

$$
\begin{array}{lllll}
\text { Ani } & \text { e-baa-si } \quad \text { yurwa } & \text { apana } & \text { uni, } & \text { ku-bun-akini } \\
\text { when } & \text { 3PP-say:IMP:PL days } & \text { up.to } & \text { three } & \text { DEP-eager-BEN } \\
\text { naberu } & \text { na a-pot-i .. } & & & \\
\text { woman } & \text { who } & \text { 3P-be.heavy-IMP } & &
\end{array}
$$

'When it was almost three days, a woman that was pregnant was eager to...'

The next example from a procedural text is the same as S2 in (10):

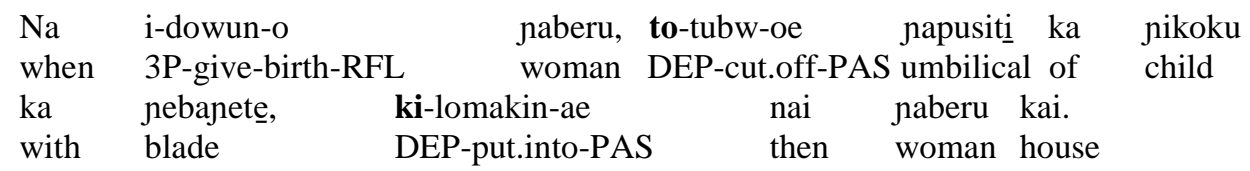

'When a woman gives birth, the umbilical cord of the child is cut with a blade. The woman is put into a house.'

The childbirth is the procedure in this paragraph. The controlling sentence Na idowuno naberu 'when a woman gives birth' uses the verb in the present tense, and thus determines tense and aspect of the following five clauses, where all verbs are marked by the $t o-/ k i$ - prefixes. The chain breaks when the next paragraph starts with $n a$ 'when':

$\begin{array}{llll}\text { Na e-lom-akin-ere } & & \text { naberu } & \text { kai, n-e-lom-ar-e-te } \\ \text { when 3P-enter-BEN-PAS } & \text { woman } & \text { house NEG-3P-enter-ABL-IMP-PL } \\ \text { yikilyoko } \quad \text { cut, } & \text { yaberu } & \text { aboni } & \text { e-lom-ar-e-te, } \\ \text { men at.all } & \text { women } & \text { alone } & \text { 3P-enter-ABL-IMP-PL } \\ \text { ku-kwan-akin-ete } & \text { yayeto. } & & \\ \text { DEP-cook-BEN-SIM } & \text { gruel } & & \end{array}$


'When the woman is brought into the hut, the men never enter at all, only women enter, cooking gruel.'

The following expository sentence is the same as S1 in (12) above. The chain starts as follows:

$\begin{array}{llllr}\text { Seke na } & \text { ecamitere } & \text { nakitasapana } & \text { yituja, isyawunete } & \text { mono } \\ \text { So when } & \text { is.wanted } & \text { to.initiate } & \text { people, begin } & \text { DM } \\ \text { nikanaka, } & \text { ki-ryama, } & \text { to-tukwo } & \text { natemari } & \text { itemokino } \\ \text { leaders } & \text { DEP-meet } & \text { DEP-discuss } & \text { that } & \text { is.appropiate } \\ \text { nide lu } & \text { erija } & \text { nesapana, } & \text { itasapanio. } & \\ \text { children who } & \text { are.not.yet } & \text { not.initiated } & \text { be.initiated } & \end{array}$

'When it is wanted (= when the leaders want) to initiate people, the generation-set leaders begin, they meet, they discuss that it is alright to initiate the children (= filial generation) who have not yet been initiated....'

The chain that begins with kiryama 'they meet' consists of twelve chained clauses (as shown in (12)), which, together with the controlling clause, constitute one paragraph. The chain ends when the next paragraph is introduced through ani iwalari 'when it dawns':

\begin{tabular}{|c|c|c|c|c|c|c|}
\hline $\begin{array}{l}\text { Ani } \\
\text { When } \\
\text { ka } \\
\text { of }\end{array}$ & $\begin{array}{l}\text { i-walari, } \\
\text { 3P-dawn, } \\
\text { jide } \\
\text { children }\end{array}$ & $\begin{array}{l}\text { ki-ryewutu } \\
\text { DEP-grind } \\
\text { yatapae. } \\
\text { porridges }\end{array}$ & $\begin{array}{l}\text { yaberu } \\
\text { wives }\end{array}$ & $\begin{array}{l}\text { kece } \\
\text { their }\end{array}$ & $\begin{array}{l}\text { tya } \\
\text { and }\end{array}$ & $\begin{array}{l}\text { taityekece } \\
\text { their.mothers }\end{array}$ \\
\hline
\end{tabular}

'When it dawns, the wives and the mothers of the children grind [and cook and bring] [calabashes with] porridge.'

\section{Conclusion}

This paper discussed the phenomenon of clause-chaining, and how clause-chained medial verb forms determine both sentence structure and the overall organization of discourse in Toposa.

Like other clause-chaining languages, Toposa follows the clause-chaining model and forms chains of clauses which are dependent on a controlling clause. All verbs in such chains are marked with a special dependency marker to-ki- which signals that the tense and aspect of these verbs are the same as those in the controlling clause, i.e. there is operator dependency. The chained clauses typically contain foregrounded information in narrative, procedural and descriptiveexpository texts, whereas background information is typically encoded in clauses with inflected verbs. Unlike most other clause-chaining languages, which are SOV, Toposa is VSO/VO, therefore the chained clauses always follow the controlling clause, and are thus post-nuclear.

Moreover, I have shown that medial verbs do not occur in subordinative or negated clauses, with the exception of means-result and purpose clauses. Coordinated contrast clauses either occur with a medial verb, when emphasizing foregrounded information, or with a finite verb, when they contain background information.

In Toposa discourse, clause chains determine the length of a paragraph. However, it happens that clauses can be inserted into a chain without disrupting the chain (skipping). These clauses are all subordinative clauses with finite verb that provide background information or metarepresentations. It was pointed out that in terms of language production the clause skipping follows the principle of economy forced by pragmatic cognitive routines that pick out the foreground or background information through the presence and absence of the clause-chaining marker to/ki.

The mechanism of clause-chaining also appears in isolated coordinated sentence constructions in that the to-/ $k i$ - dependency markers occur on verbs in the dependent clause. In such cases, however, the marking does not necessarily signal foregrounded information. 
The Toposa non-finite verb forms are motivating the structuring of narrative, procedural and expository discourse. The discourse structure follows the clause-chaining model that do not allow two independent clauses succeed each other and the clauses that do not carry the clause chaining marker are integrated into the clause chaining system though clause skipping or opening a new paragraph for the overall structuring of the discourse.

\section{Abbreviations}

$\begin{array}{ll}\text { 1P/2P/3P } & \text { first/second/third person } \\ \text { 1PL/3PL/1SG } & \text { first/third person plural, first person singular } \\ \text { ALL } & \text { allative } \\ \text { D/SG } & \text { diminutive singular } \\ \text { DEP } & \text { dependence marker } \\ \text { DER } & \text { derivational affix } \\ \text { DM } & \text { discourse marker } \\ \text { DS } & \text { different subject } \\ \text { DUR } & \text { durative } \\ \text { F/SG F/PL } & \text { feminine singular/plural } \\ \text { IMP } & \text { imperfect } \\ \text { INT } & \text { intensive } \\ \text { INF } & \text { infinitive } \\ \text { IV } & \text { imperative } \\ \text { ACC } & \text { accusative } \\ \text { NOM } & \text { nominative } \\ \text { PAS } & \text { passive } \\ \text { PER } & \text { perfective } \\ \text { M/SG } \quad \text { M/PL } & \text { masculine singular/plural } \\ \text { PL } & \text { plural } \\ \text { POSS } & \text { possessive } \\ \text { PST } & \text { past } \\ \text { SIM } & \text { simultaneous } \\ \text { SS } & \text { same subject } \\ \text { T } & \text { tense } \\ \text { YESTP } & \text { yesterday's past }\end{array}$

\section{References}

Amha, Azeb and Gerrit J. Dimmendaal. 2006. Converbs from an African perspective. In: Felix K. Ameka, Alan Dench and Nick Evans (eds.) Catching language: Issues in Grammar Writing. Berlin: Mouton de Gruyter, 393-440.

Bianti, Giorgio. 2007. Remarks on the typology of converbs and their functional equivalents in East Cushitic. In: Sascha Völlmin, Azeb Amha, Christian Rapold \& Silvia Zaugg-Coretti (eds.), Frankfurter Afrikanistische Blätter (Frankfurt African Studies Bulletin) 19. Köln: Rüdiger Köppe, 31-80. (@2010)

Callow, Kathleen. 1974. Discourse considerations in translating the Word of God. Grand Rapids: Zondervan.

Comrie, Bernhard. 1983. Switch-reference in Huichol: a typological study. In: John Haiman \& Pamela Munro 1983. Switch-reference and universal grammar. Amsterdam: John Benjamins, 17-37. 
Dooley, Robert A. 2010. Exploring clause chaining. SIL Electronic Working Papers 2010-001, 120.

Fleischman, Suzanne. 1985. Discourse functions of tense-aspect oppositions in narrative: toward a theory of grounding. Linguistics 23.6: 851-882.

Fleischman, Suzanne. 1990. Tense and narrativity: from medieval performance to modern fiction. Croom Helm romance linguistics series. London: Routledge. (Reprinted 2002.)

Grimes, Joseph E. 1975. The thread of discourse. The Hague: Mouton.

Haspelmath, Martin. 1995. The converb as a cross-linguistically valid category. In: Martin Haspelmath \& Ekkehard König (eds.), Converbs in cross-linguistic perspective. Berlin: Mouton de Gruyter, 1-55.

Haiman, John. 1980. Hua: a language of the Eastern New Guinea Highlands. Amsterdam: John Benjamins.

Haiman, John. 1983. On some origins of switch-reference marking. In: John Haiman \& Pamela Munro (eds). Switch-reference and universal grammar. Amsterdam: John Benjamins, 105-128.

Haiman, John \& Pamela Munro (eds). 1983. Switch-reference and universal grammar. Amsterdam: John Benjamins.

Haiman, John. 1987. On some origins of medial-verb morphology in Papuan Languages. University of Manitoba. Winnipeg. (Manuscript).

Hopper Paul. J. 1979. Aspect and foregrounding in discourse. In: Talmy Givón (ed.). Syntax and Semantics. Vol. 12: Discourse and syntax. New York: Academic Press, 213-241.

Hopper, Paul. 1998. Emergent Grammar. In: M. Tomasello (ed.), The New Psychology of Language. Mahwah, N.J.: Lawrence Erlbaum Associates, Publishers, 155-175.

Mungania, Basilio G. 2018. Word order in the Kiswahili clause. A Minimalist Approach. PhD Thesis. University of Nairobi. Manuscript.

Levinsohn, Stephen H. 2010. Self-instruction materials on narrative discourse analysis. SIL Intl. Online. URL: 〈https://mail.jaars.org/ bt/narr.zip>

Longacre, Robert E. (ed). 1990. Storyline concerns and word-order typology in East and West Africa. Studies in African Linguistics. Supplement 10. Department of Linguistics and the James S. Coleman African Studies Center. Los Angelos: University of California.

Longacre, Robert E. 1996. The grammar of discourse. Topics in language and linguistics. New York: Plenum. ( $2^{\text {nd }}$ edition.)

Longacre, Robert \& Shin Ja Hwang. 2012. Holistic discourse. Dallas: SIL International Publications.

MacDonald, Lorna. 1983. Tauya medial verbs. Language and Linguistics in Melanesia 14.1-2: 113137.

Mbuki, Kulwa. 2019. Clause-chaining in Kisukuma. Unpublished Master Thesis. University of Nairobi. Manuscript.

Mungania, Basilio. G. 2018. Word order in the Kiswahili clause: A Minimalist approach. Unpublished $\mathrm{PhD}$ thesis. University of Nairobi.

Myhill, John \& Junko Hibiya. 1988. The discourse function of clause-chaining. In: John Haiman \& Sandra A. Thompson (eds.), Clause combining in grammar and discourse. Amsterdam: John Benjamins, 361-398.

Payne, Thomas. E. 1997. Describing morphosyntax: a guide for field linguists. Cambridge: Cambridge University Press. 
Reinhart, Tanya. 1984. Principles of gestalt perception in the temporal organization of narrative texts. Linguistics 22: 779-809.

Roberts, John R. 1988. Amele switch-reference and the theory of grammar. Linguistic Inquiry 19: 45-64.

Sperber, Dan \& Deirdre Wilson. 1995. Relevance. Communication and Cognition. $2^{\text {nd }}$ edition. Oxford: Blackwell.

Schröder, Helga 2008. Word order in Toposa: An aspect of multiple feature-checking. SIL International and the University of Texas at Arlington. Publications in Linguistics 142.

Schröder, Helga 2011. Toposa, a clause-chaining language. Paper presented at the workshop Challenges in Nilotic languages-phonology, morphology and syntax from synchronic and diachronic perspective. Kyoto University (Kyoto), Japan. 2-4 December 2011.

Schröder, Helga 2013. Clause-chaining in Toposa, a pragmatic approach. Lodz Papers in Pragmatics Vol. 9, issue 1: 25- 44.

Schröder, Helga 2015a. Mixed pivot constraints in Toposa clause-chaining. In: Angelika Mietzner \& Anne Storch (eds) Nilo-Saharan. Models and descriptions. Cologne: Rüdiger Köppe.

Schröder, Helga 2015b. Alignment systems and passive-antipassive distribution in Nilotic languages. Journal of Language and Linguistics. 4: 42-81.

Schröder, Martin C. 2010. Toposa traditional texts. Nairobi: SIL International. Manuscript.

Stirling, Lesley. 1993. Switch-reference and discourse representation. Cambridge: Cambridge University Press.

Unger, Christoph. 2001. On the cognitive role of genre. A relevance-theoretic perspective. $\mathrm{Ph} . \mathrm{D}$. Thesis. University of London.

Unger, Christoph. 2006. Genre, discourse and global coherence. The pragmatics of discourse types. London: Palgrave Macmillan.

Unger, Christoph. 2011. Exploring the borderline between procedural encoding and pragmatic inference. In: Victoria Escandell-Vidal, Manuel Leonetti \& Aoife Ahern (eds.) Procedural Meaning: Problems and Perspectives. Current Research in the Semantics/Pragmatic interface, Vol. 25. Bingley (UK): Emerald Group Publishing, 103-127.

Van Valin, Robert D. Jr. \& Randy J. LaPolla. 1997. Syntax, meaning and function. Cambridge: Cambridge University Press.

Völlmin, Sascha et al. 2007. Converbs, medial verbs, clause chaining and related issues. Institut für Afrikansiche Sprachwissenschaften (eds.). Cologne: Rüdiger Köppe.

Helga Schröder <helga_schroeder@sil.org>

University of Nairobi

Nairobi, Kenya. 